\title{
The Impact of Corporate Governance and Investor Confidence on Earning Management: Evidence from Thai-Listed Company
}

\author{
Thanapin Attarit ${ }^{1}$ \\ ${ }^{1}$ Faculty of Business Administration, Rajamangala University of Technology Isan, Thailand \\ Correspondence: Thanapin Attarit. E-mail: thanapin@rmuti.ac.th
}

Received: April 10, $2018 \quad$ Accepted: April 26, $2018 \quad$ Online Published: May 28, 2018

doi:10.5539/ass.v14n6p123 URL: https://doi.org/10.5539/ass.v14n6p123

\begin{abstract}
The aim of the research is to study impact of corporate governance and information of investor confidence on earning management of firms listed on the Stock Exchange of Thailand. Stratified random sampling technique was employed in order to obtain the required sample of 408 Thai-listed companies. The study have excluded financial companies because their capital structure and profit are different. The study uses annual data of companies in 2015. The results showed that the highest shareholders impact on earning management, the proportion of institutional investors influencing both the earning management and investor confidence, and companies with BIG4 have an influence on investors' confidence. However, board size and CEOs Duality did not find any influence on earning management and investor confidence.
\end{abstract}

Keywords: corporate governance, investor confidence, earning management

\section{Introduction}

\subsection{Introduce the Problem}

Financial crisis in Asia on 1997 as well as WorldCom and Enron crises thoroughly any crises in the United State of America and Europe lead to the lower confidence of the investors (Alabdullah, Yahya, \& Ramayah, 2014). To call back the confidence of the investors is to use the corporate governance system which is the efficient system for the participation agency problem of the organization. By in the developing country such as Thailand, it has begun to bring the corporate governance practices to apply since 2002 until recent and it stimulates many firms in the Stock Exchange of Thailand to prompt for this change and aim to run the business toward transparency and sustainability.

From the push from corporate governance, it could result on the management to earning managent to submit the firm performance in the same way with what they want to. Earning management can be done in various ways and among those including the preparing and presentation of balance according to the accrual basis. What is most of the management normally used in earning management is to run through the residual list of the business. From the past empirical study, there is the research that supports on the concept of earning management in the business or profits decoration in the residual list in which the result has confirmed it is true according to the concept. For example, Teoh, Welch and Wong (1998) studied on earning management and found that if the net profit of the business had reduced, the business was tended to improve the residual list. Byard, Li, and Weintrop (2006) also studied about profits decoration and found that the industry leading businesses tended to improve the residual lists to add more profits to their businesses to remain as the market leader.

There was the empirical study on the measurement of business values that reflected on the investors' confidence and showed that investors can use the tools to predict the returns of common stocks investment in the future including price information and trade volume to be the information to facilitate the decision of investors on any properties. The researcher can use it as the representative for the response of confidence investors toward quantitative information as shown in the financial statement (Orens et al., 2009). For example, Price to Earnings Ratio (P/E), Price to Book Value Ratio (P/BV), Return on Asset (ROA) and Return on Equity (ROE) in that if these ratios are higher, it would reflect the more confidence of investors on the financial reports. In this study, the researcher applies the Return on Equity (ROE).

This study aims to study whether there if the impact of the corporate governance on the investors' confidence through earning management or not. It is the analysis via the influence through path analysis with the 
independent variables such as the largest size of shareholder, CEO duality, institutional ownership, Board size and type of audit firm (BIG4) with the earnings management via path analysis and measuring the confidence of investors by the Return on equity as a dependent variable.

\section{Literature Review and Hypotheses Development}

\subsection{Corporate Governance and Earnings Management}

Corporate governance is considered as a tool used to solve the conflict problems arise between the management and shareholders. As a provider, the shareholders seek for the ways to make sure that the agent or the management can well handle on their investment toward the best interest.

It is explained from Jensen and Meckling (1976) that the agency theory refers to such of relationship exists between both parties; from one hand the principals or corporation's shareholders and on another hand the management or the corporation's executives. It is argued to determine the relationship according to the explicit and implicit conditions of contract with the aims to obligate the parties to run the quite efficient as per which the activities are assigned from the shareholders to the management for the sake of their own wealth maximizing. Moreover, to delegate them with decision making authority since the lack of skills in management and tasks carry out by the shareholders themselves. In this study, the corporate governance practices that affect earning management are as follows.

\subsubsection{The Largest Shareholder and Earnings Management}

Liu and $\mathrm{Lu}$ (2007) to study in China found that earnings management measured by total accruals was significant and correlated with TOPSHARE, which indicated that management income levels increased with the interest of major shareholders. Ding, Zhang and Zhang (2007) found the highest shareholding is between $55 \%$ and $60 \%$. The results are consistent with the revenue management model (discretion), receivables, and non-operating income / sales. Concentration of ownership increases. Resulting in the highest revenue. If there is a lot of stocks, it will reduce the problem of short-term earning management.

H1: Largest shareholder has a significant positive effect on earnings management.

\subsubsection{CEO Duality and Earnings Management}

García-Meca and Sánchez-Ballesta (2009) use Meta-analysis to study CEO duality has been correlated with revenue management, with a summary model that represents a broader relationship. But other research have no relationship such as Abed, Al-Attar and Suwaidan (2012). The evidence also conflicts with the pairing of the CEO, who in the same person holds the CEO and chairperson. In theory, CEO duality have a negative impact on revenue management as they reduce the level of control required by the board and make the CEO more empowered (Chang, Luo, \& Sun, 2011).

$\mathrm{H} 2$ : CEO duality has a significant positive effect on earnings management.

\subsubsection{Institutional Ownership and Earnings Management}

Institution ownership is associated with revenue quality as institutional investors often play a dynamic role in the management of the firms by enforcing its own benefits through shareholder votes and involvement in the management of the company (Desender, 2009). Institutional investors are concerned with the low level of asymmetry of information, which is all the information that all investors pay attention to, and by expanding the business, the company will have a better income (Koh, 2003).

H3: Institutional ownership has a significant positive effect on earnings management.

\subsubsection{Board Size and Earnings Management}

Chen et al. (2006) study that the board size in China was insignificantly correlated with income management. The first factor considered was the size of the board or the number of board members. Alzoubi and Selamat, (2012) found evidence of board size and profitability as conflicting. Theoretical evidence shows a negative correlation between board size and earning quality, as large boards believe they will develop a politeness standard that prohibits effective oversight.

H4: Board size has a significant positive effect on earnings management.

\subsubsection{Large Audit Firm and Earnings Management}

Van Tendeloo and Vanstraelen, (2005) study on High Investment Opportunities, which represents the growth that high-growth businesses require using quality audits such as audit firms. The test results show that because high growth companies often have outstanding items that require high management discretion as well. 
H5: Large audit firm has a significant positive effect on earnings management.

\subsection{Earnings Management and Investor Confidence}

Investor confidence defined by return on equity (ROE), as studied by Chen et al. (2006) found that firms with lower profitability have higher of earnings management. Bowman and Navissi (2003) explain that earning management can be achieved through two methods: real income management and accrual based earning management. In Pakistan and India, Barney (2002) found that there is a significant negative relationship between earning management and firm performance.

H6: Earnings management firm has a significant positive effect on investor confidence.

\subsection{Corporate Governance and Investor Confidence}

Corporate governance is the preparation of the mechanisms of the company, procedures and structure (Alabdullah et al., 2014). It gives the shareholders the ultimate wealth through the responsibility of the manager and the people involved. Chen et al. (2009) has recently learned that the agency cost can lead to better prospects. It will lead to more efficiency and value added to the business. It will be good for the confidence of investors. In this study. The corporate governance practices that affect investors' confidence are as follows.

\subsubsection{Largest Shareholder and Investor Confidence}

It is further determined by Chen et al. (2004) the reverse U-molded association between the largest shareholders and the sapping magnitude among Chinese listed firms. However, it is found by Wang and Xiao (2009) the higher performance of the firm performance if some of the rights control are decentralized to SOE in which indicating the negative relationship of the firm's performance and the degree of control by the government. In additional, it is found by Bai et al. (2004) the increasing awareness among the other large shareholders in which result on the better performance of the firm since the corporate prospective competition and the controls as imposed by other shareholders with the aims of the largest shareholder on tunnel are the crucial determinants for the firm's performance, because prospective opposition for business control and the controls forced by other shareholders on the largest shareholder's objective to tunnel are important factors of corporate performance.

H7: Largest shareholder have a significant positive effect on investor confidence.

\subsubsection{CEO Duality and Investor Confidence}

In India, Jackling and Johl (2009) studied that CEO Duality was involved in the financial performance. In the United States 70-80 percent of them include the role of Chief Executive Officer (CEO) and President (Rhoades et al., 2001). However, widespread corporate governance in Europe separates CEOs and presidents from together While only 10 companies listed on the UK stock exchange as well as two roles (Kang \& Zardkoohi, 2005). In other areas of the world, In the middle of both terminals. In Hong Kong, it is a former British colony and has a good regulatory framework and capital market development. Combining the two roles in the same person makes the business more decisive. But in Thailand, many companies have clearly separated roles, which are in line with the good practices of the Stock Exchange of Thailand.

H8: CEO duality firm has a significant positive effect on investor confidence.

\subsubsection{Institutional Ownership and Investor Confidence}

Duggal, and Millar, (1999) fond that institutional ownership to be significantly determined by firm's presence in the S\&P 500 index. The level of involvement in the administration and the pressure of the institutional investors affects the level of correlation. Other studies conducted in Turkey found that there was a significant positive correlation between institutional ownership and investor confidence (Gürbüz, Aybars, \& Kutlu, 2010).

H9: Institutional ownership has a significant positive effect on investor confidence.

\subsubsection{Board Size and Investor Confidence}

Board number Follow the guidelines of good corporate governance. The board should be of the appropriate size. There should be no less than 5 persons and not more than 12 persons. (SET, Thailand, 2012). Jensen (1993) found that the board size of not more than 7-8 people would help to improve the operation of the business effectively. Alabdullay Yaha and Ramayah (2014) show that a significant and negative relationship between size of board and firm performance. In line with In UK, Guest, P. M. (2009) found that the number of large board companies had problems in working together. Therefore, this research assumes that the bord size is related to the firm performance.

H10: board Size has a significant positive effect on investor confidence. 


\subsubsection{Large Audit Firm and Investor Confidence}

Agency theory, the relationship between the audit firm and investor confidence. Higher quality auditing firms may control opportunistic management practices, reduce agent costs, and increase value to the company. In accordance with this combination, Aljifiri and Moustafa (2001) found that corrate between BIG4 and investor confidence.

H11: Large audit firm has a significant positive effect on investor confidence.

\section{Method}

\subsection{Data and Sample Selection}

In sample selection, the data is collected from the annual reports of the listed firms in Thailand by the end of 2015. There were 546 firms on December 31, 2015. The population of this study was 408 firms after the irrelevant were removed. The annual reports of financial year 2015 of sample companies can be downloaded from the SET website.

\subsection{Structural Equation Model}

Structural Equation Model (SEM) is used in this study for both direct and indirect relationships assessment on the corporate governance, earning management and investor confidence. The main objective of SEM is to describe on a series of consistent dependence relationships pattern among each set of latent (unobserved) constructs in which using multiple manifest (observed) variables in the measurement. In particular, SEM is well matched for causal links analysis between latent constructs (Byrne, 2001). Thus, SEM applied AMOS program for the analysis.

\subsection{Earning Management}

Sloan et al. (1996) studied the data of accruals that affect earnings quality, based on net working capital And non-cash items such as depreciation. (Depreciation) Amotized expenses are as follows:

$$
\mathrm{TACC}=[(\Delta \mathrm{CA}-\Delta \mathrm{CASH})-(\Delta \mathrm{CL}-\Delta \mathrm{STD}-\Delta \mathrm{TP})-\mathrm{DEP})] / \text { Total Asset }
$$

Where:

$\begin{array}{ll}\text { ACC } & =\text { Accruals component } \\ \Delta \mathrm{CA} & =\text { Changes in current assets } \\ \Delta \mathrm{CASH} & =\text { Change in cash account } \\ \Delta \mathrm{CL} & =\text { Changes in current liabilities } \\ \Delta \mathrm{STD} & =\text { Changes in long-term liabilities due within one year } \\ \Delta \mathrm{TP} & =\text { Changes in income tax account } \\ \mathrm{DEP} & =\text { Depreciation account and Amortization account }\end{array}$

\section{Empirical Results}

4.1 Descriptive Analysis

Table 1. Descriptive statistics for variables

\begin{tabular}{cccccc}
\hline Variables & $\mathrm{N}$ & Min & Max & Mean & S.D \\
\hline TOPSHARE & 408 & 2.73 & 95.76 & 29.53 & 17.68 \\
CEODUAL & 408 & 0 & 1 & 0.46 & 0.40 \\
INST & 408 & 0.00 & 98.11 & 33.07 & 28.96 \\
BZBOARD & 408 & 5.00 & 21.00 & 10.25 & 2.45 \\
LnBOARD & 408 & 0.70 & 1.32 & 1.00 & 0.10 \\
BIG4 & 408 & 0 & 1 & 0.65 & 0.47 \\
ROE & 408 & -79.18 & 119.04 & 27.74 & 19.54 \\
$\Delta$ CA & 408 & $-17,621.32$ & $187,739.52$ & 730.06 & 70.38 \\
$\Delta$ CASH & 408 & $-21,639.96$ & $36,192.52$ & 112.33 & 43.04 \\
$\Delta$ CL & 408 & $-44,121.34$ & $63,006.00$ & 161.46 & 92.02 \\
$\Delta$ STD & 408 & $-24,696.43$ & $36,022.36$ & 146.34 & 99.26 \\
DEP & 408 & 0.18 & $148,885.55$ & $1,421.70$ & $1,142.30$ \\
EARN & 408 & $-71,369.08$ & $50,571.64$ & -819.09 & 98.66 \\
TACC & 408 & -0.53 & 0.74 & -0.04 & 0.03 \\
\hline
\end{tabular}


TACC $=$ discretionary accruals, TOPSHARE as the high percentage of shares holder measured as the high percentage of total sharesholder, INST= Institutional ownership measured as the sum of institutional shareholder, LnBOARD as Natural log of the size of the board of directors, BIG4 as a Big4 auditing is equal to 1 if non-BIG4 firm, $0=$ auditing firm other than Big4, CEODUAL $=$ the chairman of the board of director is a dummy variable that is equal to 1 if managing director is not as chairman and 0 otherwise.

Form Table 1, TOPSHARE on average, hold around $29.53 \%$ of total shares outstanding of the sample firms. Added to this, $46 \%$ of the firms are managing director is not as chairman (CEODUAL), while the remaining 54\% are managing director is not as chairman. The results show that Institutional ownership (INST) is average of approximately $33.07 \%$. The results show that board size (BZBOARD) is ranging from five to twenty-one members with average of approximately 10 members. Added to this, $65 \%$ of the BIG4, while the remaining $35 \%$ are audited by non-Big4 firms. While, the return on equity (ROE), ranges between -79.18 percent to $119.04 \%$, the average and standard deviation for it are about $7.74 \%, 19.54 \%$, respectively. The Total accruals, TACC, ranges between about $-0.53 \%$ and $0.74 \%$, the average and standard deviation for it are about $-0.04 \%, 0.03 \%$, respectively. On average, the sample firms have negative earning management. This may indicate that Thai firms in sample are management their earnings lowly.

\subsection{Correlations Coefficients among the Variables}

Table 2. Results of Pearson correlation analysis

\begin{tabular}{cccccccc}
\hline Variables & TACC & ROE & TOPSHARE & CEODUAL & INST & LnBOARD & BIG4 \\
\hline TACC & 1 & & & & & & \\
ROE & $.231^{* * *}$ & 1 & & & & & \\
TOPSHARE & -.085 & $.159^{* *}$ & 1 & & & & \\
CEODUAL & -.015 & .024 & -.031 & 1 & & & \\
INST & .072 & $.241^{* * *}$ & $.493^{* * *}$ & .067 & 1 & & \\
LnBOARD & .097 & $.099^{*}$ & .010 & $.112^{*}$ & $.278^{* * *}$ & 1 & \\
BIG4 & -.021 & $.198^{* * *}$ & $.232^{* * *}$ & .021 & $.246^{* * *}$ & $.156^{* *}$ & 1 \\
\hline
\end{tabular}

***P-value $0.000, * * \mathrm{P}$-valueo0.01; *P-valueo0.05.

As can be seen in Table 2, it has shown the correlation coefficients between the variables and the correlation of Pair-wise between the two is lower than 0.80 . This is not considered as a problem to threaten on the regression analysis (Gujarati, 2004) while between two independent variables, there is the relatively high correlation 23.1 percent between the ROE and TACC.

\subsection{Structural Equation Model}

Table 3. Parameters of the models of before and after adjust

\begin{tabular}{cccccccc}
\hline Model & CMIN & CMIN/df & P & GFI & CFI & NFI & RMSEA \\
\hline After & 4.110 & 1.370 & 0.250 & 0.997 & 0.996 & 0.985 & 0.030 \\
Before & 200.519 & 20.052 & 0.000 & 0.880 & 0.235 & 0.257 & 0.216 \\
\hline
\end{tabular}

From Table 3, it has shown the impact of path relationships on the corporate governance and investor confidence on earning management information: the evidence from Thai-Listed is then further analyzed by the SEM using AMOS program (Byrne, 2001). Maximum Likelihood is used in this study to estimate on each parameter. The model fit include, the $\chi 2$ value is 1.370 , Goodness of Fit Index (GFI) is 0.997, Comparative Fit Index (CFI) is 0.996, Normed Fit Index (NFI) is 0.973 , and the root mean square error of approximation is 0.030 . Therefore, the structural equation is consistent and appropriate.

In Table 4, the investigative results are listed for the hypothesized research model. The research model shows the acceptable relevant fit indices

\subsection{Hypothesis Test and Discussion}

In Table 4, hypothesis supporting results in regard of the relationship between earning management and corporate governance is expected in $\mathrm{H} 2, \mathrm{H} 3$ and $\mathrm{H} 5$. TOPSHARE is positively and significantly related to the total accrual at the level of 5\% thus, this support on hypothesis H1. It is consistent with the former research in which found that TOPSHARE has the positive and significant total accrual in China (Liu \& Lu. (2007). In China, it is found that the corporate governance and earning management with the measuring of earning management via TACC is correlated and significant to TOPSHARE. This indicated the higher management income levels and 
the interests for major shareholders. It is pointed out that in China, the company's information need to be carefully interpreted since there are usually other incentives and many things in managing revenue. Institutional ownership is positively and significantly related to the total accrual at the level of $5 \%$ thus, it has supported on hypothesis H4. This seems consistent with the previous research in which found out that institutional ownership is the one that access into the useful internal information on future perspective, business strategies, and so on via the management direct contact (Nouravesh \& Ebrahimi, 2005). There are chances for institutional investors with the ability and resources for manages monitoring in which it is suggested that the efficient monitoring is related to the better institutional ownership monitoring on management activities to lessen the potential of monopolizing of managers on the opportunistically earnings (Koh, 2003).

Table 4. Parameter estimates for hypothesized paths in structure equation model

\begin{tabular}{cccccc}
\hline Research hypothesis & \multicolumn{2}{c}{ Path description } & Result ( $(\beta)$ Coefficient & P-value \\
\hline H1 & TOPSHARE & $--->$ & TACC & -0.146 & $.011^{*}$ \\
H2 & LnBOARD & $--->$ & TACC & 0.069 & .182 \\
H3 & BIG4 & $--->$ & TACC & -0.031 & .547 \\
H4 & INST & $--->$ & TACC & .0135 & $.023^{*}$ \\
H5 & CEODUAL & $--->$ & TACC & -0.035 & .469 \\
H6 & TACC & $--->$ & ROE & 0.229 & $.000^{* * *}$ \\
H7 & TOPSHARE & $--->$ & ROE & 0.071 & .192 \\
H8 & LnBOARD & $--->$ & ROE & 0.010 & .840 \\
H9 & BIG4 & $--->$ & ROE & 0.148 & $.002^{* *}$ \\
H10 & INST & $--->$ & ROE & 0.149 & $.008^{* *}$ \\
H11 & CEODUAL & $--->$ & ROE & 0.016 & .738 \\
\hline
\end{tabular}

***P-value $0.000, * * \mathrm{P}$-valueo $0.01 ; * \mathrm{P}$-valueo 0.05 .

Higher profitability of the firms can be measured by ROE in which to engage more with the earnings management (positive and significant coefficients to ROE). It is normal for this positive relation as it is consistent with the results from the study by Chen \& Yuan (2004). Among the explanation of the positive relation, Stock Exchange of Thailand is mentioned with requirements for the firms to achieve the minimum profitability as to keep being in the list and to apply for the permission for more shares issuing.

\section{Concussion}

Corporate governance has influence on earning management, ie, the proportion of shareholders (TOPSHARE) correlates with earning management at significant level of 0.05 . This indicate that the proportion of shareholding inc, resulting in a higher profit margin. The findings are consistent with the findings of Fan \& Wong (2002). The ownership structure and recognition of Asian accounting earnings have a negative correlation. The high concentration of shareholders in Asia, which is often a high concentration of shareholders, will have a direct impact on financial quality as the controlling shareholders take advantage of the benefits. From minority shareholders through non-returnable operations to minority shareholders, or by limiting their rights. Under the rules, all shareholders have the right to vote at meetings, but because of the minority shareholdings, they cannot be refrigerated and law enforcement is required. The weakening of the protection of minority shareholders' rights. In addition, the results show that Institutional Share (INST) has an influence on profitability. In line with Hashim and Devi (2007), the effect of corporate governance on profitability in Malaysia is examined. Desender, (2009) found that the proportion of institutional investors was correlated with the quality of income. Because institutional investors tend to have an active role in the management of the company by forcing shareholders and stakeholders involved in the management of the company.

There are some research limitations to consider when the findings are interpreting. First, there is the bias in the sample selection as it is done based on a predetermined criterion, not a random method. However, since there is the limited firm number to disclose the relevant and comprehensive corporate governance to public, it is quite hard to study on corporate governance in Turkey by randomly firm selection. As result, another concern in on the limited size of sample.

\section{Acknowledgements}

The authors would like to thank the Research and Development Institute of Rajamangala University of Technology Isan, Thailand for financially supporting this research under Contract of Faculty of Business Admiration. 


\section{References}

Abed, S., Al-Attar, A., \& Suwaidan, M. (2012). Corporate governance and earnings management: Jordanian evidence. International Business Research, 5(1), 216-225.

Alabdullah, T. T. Y. (2016). Are board size and ownership structure beneficial in emerging markets' firms? Evidence from Jordan. International Journal of Management \& Information Systems, 20(3), 87-94. https://doi.org/10.19030/ijmis.v20i3.9752

Alabdullah, T. T. Y., Yahya, S., \& Ramayah, T. (2014). Corporate governance development: new or old concept. European Journal of Business and Management, 6(7), 312-315.

Alabdullah, T.T.Y., Yahya, S., \& Ramayah, T. (2014). Corporate governance mechanisms and Jordanian companies' financial performance. Asian Social Science, 10(22), 247.

Alabdullah, T. T. Y., Yahya, S., Nor, M., \& Majeed, F. (2016). An investigation of corporate governance from a new perspective: examining the financial performance of companies and the impact of executive turnover. Corporate Board: Role, Duties \& Composition, 12(1), 53-67. https://doi.org/10.22495/cbv12i1art6

Alzoubi, E. S. S., \& Selamat, M. H. (2012). The effectiveness of corporate governance mechanisms on constraining earning management: Literature review and proposed framework. International Journal of Global Business, 5(1), 17-35.

Bai, C., Liu, Q., Lu, J., \& Song, F. M. (2004). Corporate governance and market valuation in China. Journal of Comparative Economics, 32, 599-616. https://doi.org/10.1016/j.jce.2004.07.002

Barney, J. B. (2002). Gaining and Sustaining Competitive Advantage. Prentice-Hall: Upper Saddle River, NJ.

Bowman, R. G., \& Navissi, F. (2003). Earnings management and abnormal returns: Evidence from the 19701972 Price Control Regulations. Accounting \& Finance, 43(1), 1-19. https://doi.org/10.1111/1467-629X.00080

Byard, D., Li, Y., \& Weintrop, J. (2006). Corporate governance and the quality of financial analysts' information. Journal of Accounting and Public policy, 25(5), 609-625. https://doi.org/10.1016/j.jaccpubpol.2006.07.003

Byrne, B. M. (2001). Structural Equation Modeling with AMOS, EQS and LISREL: comparative approaches to testing for the factorial validity of a measuring instrument. International Journal of Testing, 1(1), 55-86. https://doi.org/10.1207/S15327574IJT0101_4

Byrne, B. M. (2001). Structural Equation Modeling with AMOS: Basic Concepts, Applications, and Programming. NJ: Lawrence Erlbaum Associates, Inc.

Chang, J. C., Luo, M., \& Sun, H. L. (2011). The impact of independent and overlapping board structures on CEO compensation, pay-performance sensitivity and accruals management. Quarterly Journal of Finance \& Accounting, 54-84.

Chantakhet, N. (2011). A Study of the Relationship between Corporate Governance and Operating Results of the Listed Companies in the Stock Exchange of Thailand, SET 100 Group (Doctoral dissertation, University of the Thai Chamber of Commerce (UTCC)).

Chen, G., Firth, M., Gao, D. N., \& Rui, O. M. (2006). Ownership structure, corporate governance, and fraud: Evidence from China. J. of Corp. Finance, 12(3), 424-448. https://doi.org/10.1016/j.jcorpfin.2005.09.002

Chen, K., \& Yuan, H. (2004). Earnings management and capital resource allocation: evidence from China's accounting-based regulation of rights issue. The Accounting Review, 74, 645-665. https://doi.org/10.2308/accr.2004.79.3.645

Chen, X., Chen, D., \& Zhu, K. (2004a). Ownership structure and firm performance in China: A survey. China Accounting and Finance Review, 6(4), 1-47.

Cornett, M. M., McNutt, J. J., \& Tehranian, H. (2009). Corporate governance and earnings management at large US bank holding companies. Journal of Corporate finance, 15(4), 412-430. https://doi.org/10.1016/j.jcorpfin.2009.04.003

Desender, K. A., Aguilera, R. V., Crespi-Cladera, R., \& Garcia-Cestona, M. A. (2009). Board characteristics and audit fees: Why ownership structure matters. University of Illinois at Urbana-Champaign, College of Business WP, 09-0107.

Ding, Y., Zhang, H., \& Zhang, J. (2007). Private vs state ownership and earnings management: evidence from Chinese listed companies. Corporate Governance: An International Review, 15(2), 223-238. 
https://doi.org/10.1111/j.1467-8683.2007.00556.x

Duggal, R., \& Millar, J. A. (1999). Institutional ownership and firm performance: The case of bidder returns. Journal of Corporate Finance, 5(2), 103-117. https://doi.org/10.1016/S0929-1199(98)00018-2

Fan, J. P. H., \& Wong, T. J. (2002). Corporate ownership structure and the informativeness of accounting earnings in East Asia. Journal of Accounting and Economics, 33, 401-425. https://doi.org/10.1016/S0165-4101(02)00047-2

García-Meca, E., \& Sánchez-Ballesta, J. P. (2009). Corporate governance and earnings management: A metaanalysis. Corporate governance: An international review, 17(5), 594-610. https://doi.org/10.1111/j.1467-8683.2009.00753.x

Guest, P. M. (2009). The impact of board size on firm performance: evidence from the UK. The European Journal of Finance, 15(4), 385-404. https://doi.org/10.1080/13518470802466121

Gujarati. (2004). Basic econometrics (2nd ed.). The McGraw-Hill Companies.

Gürbüz, A. O., Aybars, A., \& Kutlu, Ö. (2010). Corporate governance and financial performance with a perspective on institutional ownership: Empirical evidence from Turkey. Journal of Applied Management Accounting Research, 8(2), 21.

Jackling, B., \& Johl, S. (2009). Board structure and firm performance: Evidence from India's top companies. Corporate Governance: An Int. Review, 17(4), 492-509. https://doi.org/10.1111/j.1467-8683.2009.00760.x

Jensen, M. C., \& Meckling, W. H. (1976). Theory of the firm: Managerial behavior, agency costs and ownership structure. Journal of financial economics, 3(4), 305-360. https://doi.org/10.1016/0304-405X(76)90026-X

Kang, E., \& Zardkoohi, A. (2005). Board leadership structure and firm performance. Corporate governance: an international review, 13(6), 785-799. https://doi.org/10.1111/j.1467-8683.2005.00470.x

Koh, P.-S. (2003). On the association between institutional ownership and aggressive corporate earnings management in Australia. The British Accounting Review, 35(2), 105-128. https://doi.org/10.1016/S0890-8389(03)00014-3

Liu, Q., \& Lu, Z. J. (2007). Corporate governance and earnings management in the Chinese listed companies: A tunneling perspective. Journal of Corporate Finance, 13(5), 881-906. https://doi.org/10.1016/j.jcorpfin.2007.07.003

Nouravesh, I., \& EbrahimiKordelor, A. (2005). Investigate \& Explain the Relationship Shareholders Composition with Information Asymmetry \& the Usefulness of Performance Accounting Measures. Journal of Accounting \& Audit Investigations, 42, 97-124

Orens, R., Aerts, W., \& Lybaert, N. (2009). Intellectual capital disclosure, cost of finance and firm value. Management Decision, 47(10), 1536-1554. https://doi.org/10.1108/00251740911004673

Rhoades, D. L., Rechner, P. L., \& Sundaramurthy, C. (2001). A Meta-analysis of Board Leadership Structure and Financial Performance: are "two heads better than one"? Corporate Governance: An International Review, 9(4), 311-319. https://doi.org/10.1111/1467-8683.00258

Rouf, M. (2011). The relationship between corporate governance and value of the firm in developing countries: Evidence from Bangladesh. The International Journal of Applied Economics and Finance, 5, 237-244. https://doi.org/10.3923/ijaef.2011.237.244

Sloan, R. G. (1996). Do Stock Prices Fully Reflect Information in Accruals and Cash.

Teoh, S. H., Welch, I., \& Wong, T. J. (1998). Earnings management and the long-run market performance of initial public offerings. The Journal of Finance, 53(6), 1935-1974. https://doi.org/10.1111/0022-1082.00079

Van Tendeloo, B., \& Vanstraelen, A. (2005). Earnings management under German GAAP versus IFRS. European Accounting Review, 14(1), 155-180. https://doi.org/10.1080/0963818042000338988

Wang, K., \& Xiao, X. (2009). Ultimate government control structure and fair value: Evidence from Chinese listed companies. China J. of Accounting Res., 2(1), 13-50. https://doi.org/10.1016/S1755-3091(13)60010-6

\section{Copyrights}

Copyright for this article is retained by the author(s), with first publication rights granted to the journal.

This is an open-access article distributed under the terms and conditions of the Creative Commons Attribution license (http://creativecommons.org/licenses/by/4.0/). 